\title{
Measured Performance and Stability Analysis of Large-Scale Reinforced Model Embankments at Different Moisture Contents
}

\author{
Danial Esmaili $^{1,2} \cdot$ Kianoosh Hatami $^{1}$
}

Received: 29 May 2015/ Accepted: 26 June 2015/Published online: 9 July 2015

(C) Springer International Publishing AG 2015

\begin{abstract}
This paper describes construction and instrumentation of two $1.65-\mathrm{m}$ high reinforced embankment models that were tested at two different gravitational water contents (GWC) on the dry and wet sides of the optimum moisture content (OMC); i.e. $\mathrm{OMC}-2 \%$ and $\mathrm{OMC}+2 \%$. The embankment models were constructed using a clayey sand that was reinforced with four layers of instrumented geotextile with a uniform vertical spacing of $300 \mathrm{~mm}$. Each model embankment was subjected to a line surcharge load (strip footing) near its crest until failure. The magnitudes of GWC, earth pressure, geotextile strains, footing settlement and embankment deformations were measured using EC-5 sensors, earth pressure cells, wire potentiometers, linear variable deferential transformers and reference plates, respectively during the construction and loading phases of each test. The GWC values in each model embankment were measured using EC-5 sensors and the oven drying method to ensure that they were close to the target values. Slope stability analysis was carried out to study the equilibrium of embankment models and to validate the predicted bearing capacity and factor of safety results against the experimental data. Results of this study show that the embankment model constructed on the dry
\end{abstract}

Kianoosh Hatami

kianoosh@ou.edu

Danial Esmaili

danial.esmaili@dot.gov

1 School of Civil Engineering and Environmental Science, The University of Oklahoma, 202 W. Boyd St., Room 334, Norman, OK, USA

2 Present Address: Federal Highway Administration, Turner Fairbank Highway Research Center, Room F206, 6300 Georgetown Pike, Mclean, VA, USA side of OMC (i.e. OMC-2 \%) had a $10 \%$ greater serviceability failure load than the model built at $\mathrm{OMC}+2 \%$. Meanwhile, stability analysis results indicate that the bearing capacity of an unreinforced model embankment at OMC $-2 \%$ would be $72 \%$ lower than that of the corresponding reinforced model. It is also found that compaction-induced energy could increase the earth pressure within the embankment by up to $70 \%$ of the vertical stress in the soil mass due to gravity.

Keywords Reinforced soil embankments - Unsaturated marginal soils $\cdot$ Soil-reinforcement interface $\cdot$ Bearing capacity · Geotechnical instrumentation · Moisture reduction factor $\cdot$ Stability analysis

\section{Introduction}

Landslides and slope failures along highways are often reconstructed and repaired using locally available soils that can contain significant amounts of fines due to otherwise prohibitive costs of producing and transporting freedraining coarse-grained materials. One of the established and cost-effective remedial construction methods to stabilize slopes and embankments in highway and urban development projects involves the use of geosynthetic reinforcement. However, one main concern in using soils with considerable amounts of fines (e.g. greater than $15 \%$ ) in reinforced soil structures is that their stability and performance are susceptible to variations in their moisture content. Concerns related to the use of fine-grained and marginal quality soils in geotechnical construction such as strain-softening behavior, loss of strength and excessive deformation have been discussed extensively in the literature [1-18]. However, the influence of moisture content on 
the shear strength and performance of marginal soilgeosynthetic reinforcement interface has not been investigated adequately to lead to reliable design.

As part of a long-term research study, the authors have investigated the influence of suction and moisture content in different marginal soils on the soil-reinforcement interface behavior through a series of multi-scale direct shear and pullout tests in the laboratory [5, 6, 8-11, 13]. In those studies, a moisture reduction factor (MRF) was introduced to quantify the anticipated loss in the soil-reinforcement interface shear strength as a result of increased moisture content in the soil due to factors such as precipitation and water infiltration. More recently, the authors extended their database of MRF values to those obtained from reduced-scale embankments [5, 12]. It was found that embankment-based MRF values were consistent with those obtained using the elemental interface shear tests (i.e. direct shear and pullout tests) in earlier studies. It was also found that the interface shear strength could decrease by as much as $50 \%$ if the gravitational water content (GWC) in the soil increases from $\mathrm{OMC}-2 \%$ to $\mathrm{OMC}+2 \%$, which could lead to excessive deformations or even instability of the embankment structure due to wetting.

The study reported in this paper extends the authors' earlier findings to the measured performance of large-scale reinforced embankments that were constructed with a marginal quality soil (clayey sand) at two different GWC (i.e. $\mathrm{OMC}-2 \%$ and $\mathrm{OMC}+2 \%$ ). Slope stability analysis was carried out using GSTABL [19] and the results were validated against the measured data. The contribution of reinforcement in the stability of model embankments was subsequently investigated through additional stability analysis of reinforced versus unreinforced models

\section{Large-Scale Test Facility}

Figure 1 shows the large-scale outdoor test facility that was used to carry out the embankment tests reported in this paper. The external dimensions of the reinforced concrete test box are $5 \mathrm{~m}(\mathrm{~L}) \times 3 \mathrm{~m}(\mathrm{~W}) \times 2.8 \mathrm{~m}(\mathrm{H})$. The walls of the test facility are $0.3 \mathrm{~m}$ thick on all three sides and the test box is flanked by two buttress columns that support the steel loading frame and two 180-ton-capacity hydraulic cylinders. The reinforced concrete floor of the box provides a rigid foundation for the model walls and embankments that are constructed and tested in the facility. An earthen access ramp was built on the east side of the test box to facilitate the transportation and placement of the soil inside the box during construction. The sidewalls of the test box were coated with polyurethane to reduce the friction with the embankment soil during the tests.
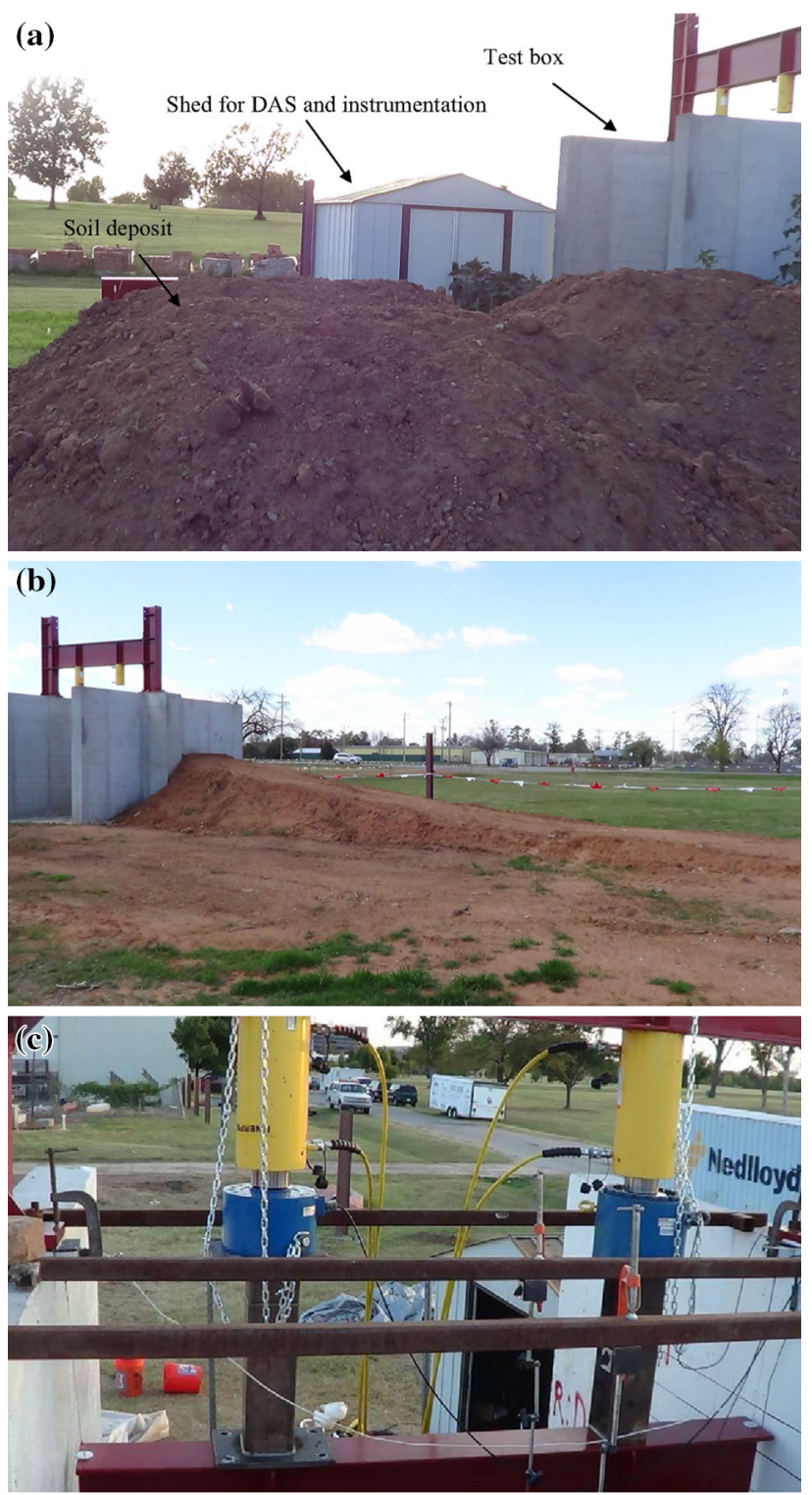

Fig. 1 a Large-scale outdoor test facility for reinforced soil walls and embankments at OU; b ramp for transporting soil to the test box using a front loader; c loading assembly

\section{Materials}

\section{Soil}

The soil used in this study was a clayey sand which contained $2 \%$ (by weight) of a high grade sodium bentonite commercially known as SUPER GEL-X. The bulk of the sandy soil had been obtained from a local highway interchange project in Norman, OK, after a period of search for a source of low-plasticity soil in significant quantities (approximately 40 cubic meters) for the outdoor embankment tests in this study. However, the soil from this borrow source was essentially non-plastic whereas in this study 
Table 1 Properties of the embankment soil (blended sand-SUPER GEL-X) used in this study

\begin{tabular}{ll}
\hline Property & \multicolumn{1}{c}{ Value } \\
\hline Liquid limit (\%) & 25 \\
Plastic limit (\%) & 17 \\
Plasticity index (\%) & 8 \\
Specific gravity & 2.65 \\
Gravel (\%) & 36.2 \\
Sand (\%) & 37.1 \\
Silt (\%) & 21.7 \\
Clay (\%) & 5 \\
Maximum dry unit weight $\left(\mathrm{kN} / \mathrm{m}^{3}\right)^{\mathrm{a}}$ & 20.6 \\
Optimum moisture content $(\%)^{\mathrm{a}}$ & 10.1 \\
Cohesion at OMC-2 \% and OMC+2 \% $(\mathrm{kPa})^{\mathrm{b}}$ & $12.2,10.8$ \\
Friction angle at OMC-2 \% and OMC+2 \% $\left(^{\circ}\right)^{\mathrm{b}}$ & $37.5,34.3$ \\
Suction at OMC-2 \% and OMC+2 \% $(\mathrm{kPa})^{\mathrm{c}}$ & 500,900 \\
\hline a Modified proctor tests [28] & \\
b Shear strength properties of the soil were determined according to \\
ASTM D3080 [29]
\end{tabular}

some plasticity was desired to represent a marginal quality soil that would exhibit measureable change in matric suction over the range between $\mathrm{OMC}-2 \%$ and $\mathrm{OMC}+2 \%$. Therefore, several trial percentages of sodium bentonite were blended with the sandy soil before a suitable blend of soil was obtained for the embankment tests with the properties as listed in Table 1. A series of sieve analysis and hydrometer tests were carried out on the blended soil according to ASTM D422 and ASTM D1140 [20, 21] with the results as shown in Fig. 2. The blended soil is classified as $\mathrm{SC}$ according to the unified soil classification system (USCS) with $500-900 \mathrm{kPa}$ of suction for the GWC values within the range between 8.1 and $12.1 \%$.

\section{Reinforcement}

A woven polypropylene (PP) geotextile (Mirafi HP370) was used as the embankment reinforcement in the largescale tests. Selected properties of the HP370 geotextile in machine direction (MD) and the shear strength of its interface with the embankment soil are given in Table 2 .

\section{Construction of Model Embankments}

Before the construction of the test embankments, the embankment soil was prepared by spreading the calculated amount of the sandy soil for every two lifts from the borrow source near the test facility and taking five samples from three levels (top, middle and bottom) to determine its initial GWC value. Then, $2 \%$ by weight of SUPER GEL-X
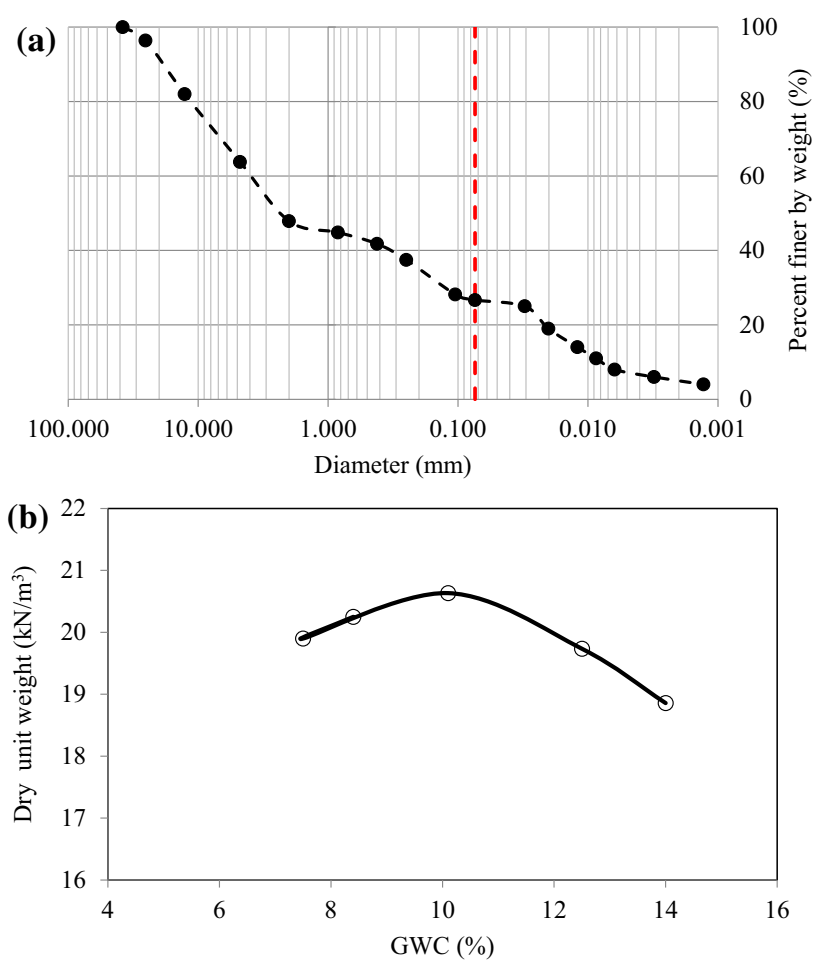

Fig. 2 a Gradation curve from sieve analysis and hydrometer tests on the embankment soil; b compaction curve from modified Proctor tests. Dashed line indicates the location of $0.075 \mathrm{~mm}$

and a target amount of water was added to the sand and mixed using a tractor-tiller to reach the target GWC value (i.e. OMC $-2 \%$ or $\mathrm{OMC}+2 \%$ depending on the test case). Afterwards, additional samples were taken from the blended soil to determine its actual GWC value for verification using the oven drying method [22].

The blended soil was subsequently transported to the test box through an access ramp using a front loader machine (Fig. 1b) and was compacted in 11 150-mm lifts to $95 \%$ of its maximum dry unit weight $\left(\gamma_{\text {dmax }}=20.6 \mathrm{kN} /\right.$ $\mathrm{m}^{3}$ ) using a pneumatic rammer. Regular soil samples were taken throughout the construction process to ensure that the soil density and GWC values remained consistently near their target values within the embankment.

The embankment was reinforced with four $1500 \mathrm{~mm}$ long instrumented geotextile layers at a uniform spacing of $300 \mathrm{~mm}$. Compaction of each soil lift took approximately $45 \mathrm{~min}$. Then, several brass tube samples at seven different locations throughout each lift were taken to determine the as-compacted GWC and dry unit weight (i.e. degree of compaction) for each lift using the oven-drying [22] and rubber balloon [23] test methods (Fig. 3). The soil density and GWC values for each lift were measured twice; i.e. immediately after compaction and immediately before the placement of the following lift. Figure $3 \mathrm{a}$ shows the marked-up geogrid template that was used to take 
Table 2 Properties of the woven geotextile reinforcement used in the embankment tests (Mirafi HP370) and its interface with embankment soil

\begin{tabular}{|c|c|c|c|}
\hline Property & ASTM test method & Unit & $\begin{array}{l}\text { HP370 MARV/ } \\
\text { MaxARV (MD) }\end{array}$ \\
\hline Ultimate tensile strength & D4595 [30] & $\mathrm{kN} / \mathrm{m}$ & 52.5 \\
\hline Tensile strength (at $5 \%$ strain) & D4595 [30] & $\mathrm{kN} / \mathrm{m}$ & 21.9 \\
\hline Factory seam strength & D4884 [31] & $\mathrm{kN} / \mathrm{m}$ & 24.6 \\
\hline Permeability & D4491 [32] & $\mathrm{mm} / \mathrm{s}$ & 0.5 \\
\hline Permittivity & D4491 [32] & $\mathrm{s}^{-1}$ & 0.52 \\
\hline Apparent opening size (AOS) & D4751 [33] & $\mathrm{mm}$ & 0.6 \\
\hline \multicolumn{4}{|l|}{ Soil-geotextile interface property } \\
\hline Interface adhesion at $\mathrm{OMC}-2 \%, \mathrm{OMC}$ and $\mathrm{OMC}+2 \%$ & D5321 [34] & $\mathrm{kPa}$ & $17.9,12.4,11.7$ \\
\hline Interface friction angle at $\mathrm{OMC}-2 \%, \mathrm{OMC}$ and $\mathrm{OMC}+2 \%$ & D5321 [34] & $\left({ }^{\circ}\right)$ & $27.8,24.9,21.8$ \\
\hline
\end{tabular}

consistent soil samples from the embankment during construction. At the end of each day throughout the construction stage, the embankment was covered with a heavyduty tarp to preserve the soil moisture content. After the embankment was fully constructed, the facing slope was trimmed to the target slope angle of $69.5^{\circ}$ from horizontal to complete the construction stage before the model was subjected to surcharge loading. This facing angle was selected as the steepest reinforced soil slope as classified by FHWA guidelines [24] so as to instigate the largest deformations possible for the applied loading.

\section{Instrumentation}

Several different sensors were used to measure the soil gravimetric water content (GWC), earth pressures, embankment deformations and geotextile strains (Figs. 4, 5). Nine EC-5 sensors were used near the soil-geotextile interfaces to monitor the GWC values during construction and loading stages of the tests. EC-5 sensors are capable of continuous reading of the soil volumetric water content which is related to the GWC through the following relationship:

$\theta_{\mathrm{v}}=w \times \frac{\rho_{\mathrm{d}}}{\rho_{\mathrm{w}}}$,

where $\theta_{\mathrm{v}}$ is the volumetric water content (VWC), $w$ the gravimetric water content (GWC), $\rho_{\mathrm{d}}$ the dry density of the soil, $\rho_{\mathrm{w}}$ the density of water.

Three EPC sensors were used to measure the vertical pressure within the soil and three LVDTs were used to monitor the vertical deformation of embankment surface near the loading beam. Two WPs were used to measure the footing settlement $10 \mathrm{~mm}$ from each end of the loading beam. Facing deformation was measured using eight 25-mm square plates that were mounted on the embankment facing at the end of construction and additional direct measurements that were taken using tape measure and level from two observation (reference) poles that had been installed in front of the facing (Fig. 4). Additionally, 16 wire potentiometers (WP) were collectively attached to the four reinforcement layers to determine their global strains (Fig. 5).

\section{Loading of Model Embankments}

The target location of the loading beam on the top of the embankment with a plan area of $2.35 \mathrm{~m}(L) \times 0.20 \mathrm{~m}$ $(W)$ was first leveled to prevent any rotation of the beam during loading. Then, the beam was moved to the test box using a forklift and it was placed on the embankment at a distance of $455 \mathrm{~mm}$ from the crest (center of loading beam to the crest). Then, two 200-ton-capacity load cells that had been calibrated were placed on the loading beam and were tied to the reaction beam using two long chains to secure them in place upon embankment failure. The surcharge load on each model embankment was applied using two 200-ton, 300-mm stroke hydraulic cylinders (Enerpac Model CLRG-20012) and an Enerpac electric pump (Model ZU4420SB) as shown in Fig. 1c. The loading was applied in $15 \mathrm{kPa}$ increments while the beam settlement and embankment facing deformations were monitored. Subsequent load increments were applied only after the loading beam and embankment deformations stabilized following each load increment. This process was repeated until a clear and continuous slip surface was started from the top of the embankment and extended to the slope.

\section{Results}

\section{GWC and Density of the Embankment Soil}

Figures 6 and 7 show example distributions of the soil gravimetric water content (GWC) in each lift within the 
Fig. 3 a Marked-up geogrid template indicating sampling locations for moisture content and density in each compacted lift (dimensions in $\mathrm{mm}$ ); $\mathbf{b}$ brass tube samples to measure soil density; c rubber balloon measurement of soil density

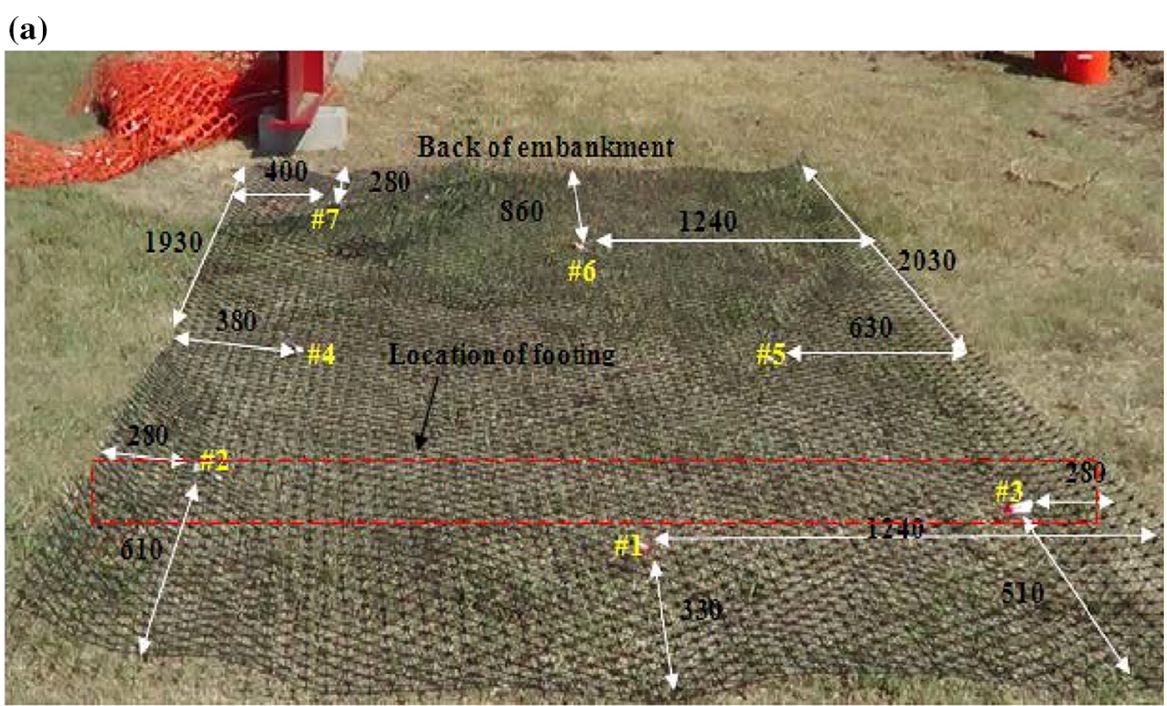

(b)
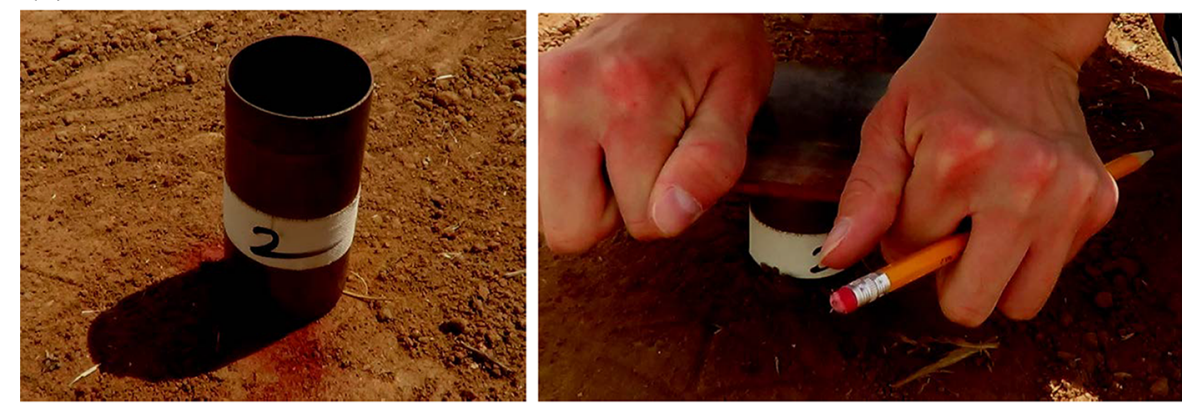

(c)
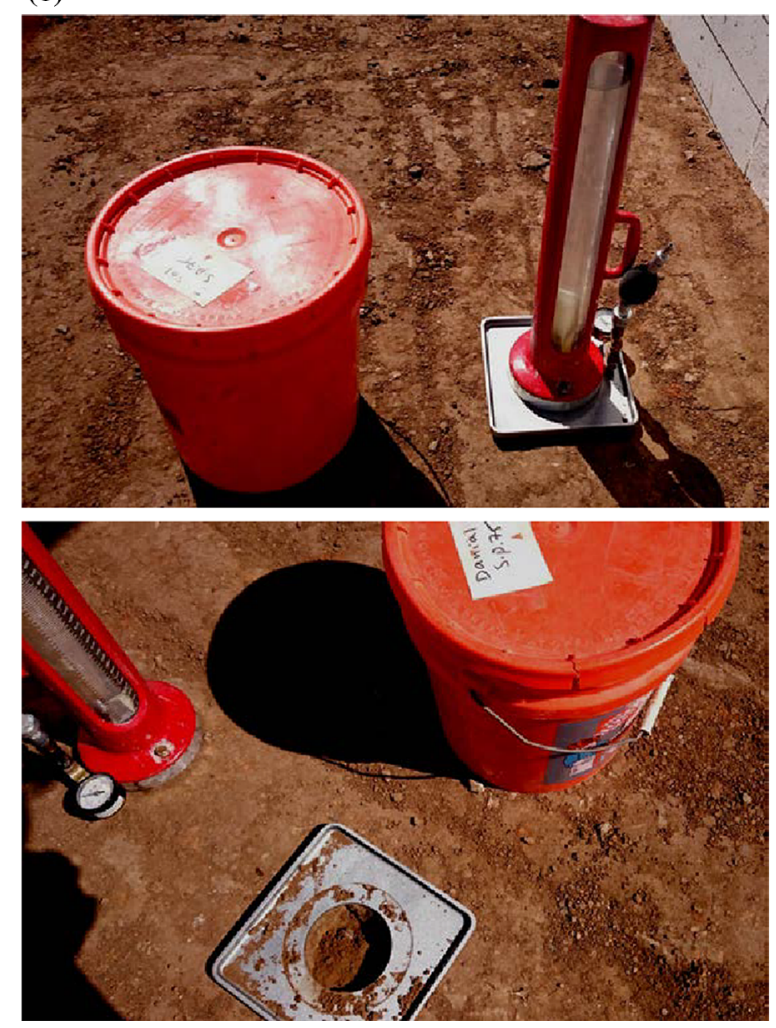

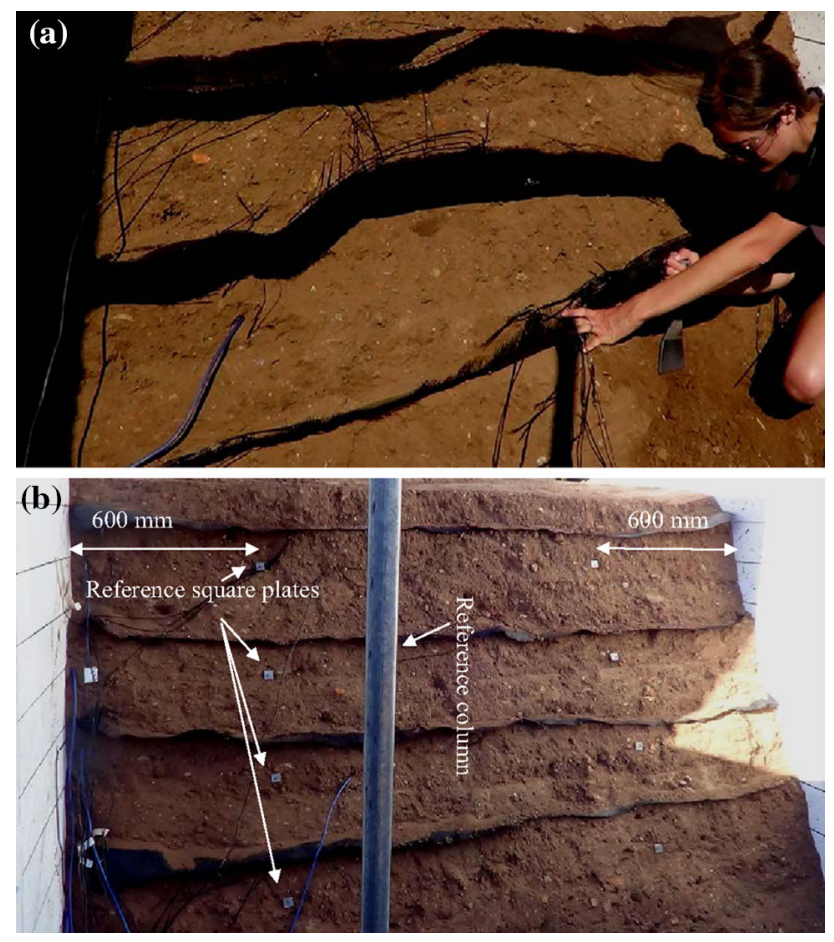

Fig. 4 a Trimming of model embankments facing to the target slope angle; b locations of reference plates on the facing to measure its deformations

model embankments as measured using oven-drying method and EC-5 sensors at locations 1 through 7 (Fig. 3a) during construction and after the completion of the loading phase. Results in Figs. 6 and 7 indicate that the GWC values throughout the model embankments deviated from the target values by as much as approximately $1.5 \%$ on either side of the OMC. However, given that processing of the soil and setting up and carrying out the tests were all carried out outdoors and the length of time that was needed to complete the entire operation, it can be concluded that by and large, the GWC values throughout the model embankments were stable and uniform during both the construction and loading phases as practically as possible for outdoor embankment models.

Figure 8 shows the variations in the soil dry density and degree of compaction throughout the embankment at OMC $-2 \%$ measured using oven-dried samples and rubber balloon methods at locations 1 through 7 . Care was taken to compact each lift with equal amount of energy (i.e. equal passes of compactor equipment). However, measured values for the degree of compaction in Fig. 8 indicate that the degree of compaction over the entire embankment varied between 85 and $89 \%$ (equivalent densities between 1750 and $1835 \mathrm{~kg} / \mathrm{m}^{3}$, respectively). Apart from the natural spatial variation of density throughout the embankment, the observed difference could partly be attributed to possible disturbance of the local soil during sampling. Nevertheless, results shown in Fig. 8 show an overall mean density value of $1790 \mathrm{~kg} / \mathrm{m}^{3}$ (equivalent to $87 \%$ degree of compaction) with a $\pm 2.5 \%$ variation around the mean value, which could be regarded as acceptable for field construction.

\section{Load-Settlement and Earth Pressure Response}

Figure 9 shows the load-settlement data for the model embankments constructed at $\mathrm{OMC}-2 \%$ and $\mathrm{OMC}+2 \%$. The settlement results are the mean values of two wire potentiometers that were mounted near the two opposite ends of the loading beam as shown in Fig. 1c. The vertical wire potentiometers recorded comparable settlements throughout the loading phase with the maximum differential settlement equal to $3 \mathrm{~mm}$. The serviceability failure loads of the two embankments based on a $25-\mathrm{mm}$ settlement criterion and the ultimate failure loads based on precipitous increase in settlements are also shown in Fig. 9.

Results in Fig. 9 indicate that the serviceability failure pressure of the drier embankment based on a $25-\mathrm{mm}$ settlement criterion is $440 \mathrm{kPa}$ which is $10 \%$ greater than the failure pressure for the wetter embankment. However, the wetter embankment eventually failed at an ultimate pressure of $600 \mathrm{kPa}$ which is $33 \%$ greater than the ultimate pressure measured for the drier embankment. The authors believe that the as-placed moisture content, density and sodium bentonite concentration are among the most important factors that could have influenced the embankment soil properties and performance. In both test embankments, the moisture content and density of the soil were continuously measured for each lift using different methods. The corresponding data which are shown in Figs. 6, 7 and 8 are judged to be consistent and well within the target values for an outdoor test embankment. Therefore, since the type and quantity of the reinforcement and the construction method were also the same between the two test embankments, one plausible explanation for an ultimately larger failure load for the wetter embankment could be a slightly larger amount of sodium bentonite that might have inadvertently been blended with the soil during the soil processing phase of the construction operation near the test facility. Results of several previous studies (e.g. [25]) have also shown that the performance and stability of reinforced soil embankments and retaining walls can be highly sensitive to the amount of cohesion in the embankment soil, which would be consistent with these test results. This observation indicates that cohesion has a significant contribution in the stability of embankments and reinforced soil slopes. As a result, a series of slope stability analyses was carried out to predict the failure load for the model embankment that was constructed at $\mathrm{OMC}+2 \%$ with an identical amount of bentonite blended with the 
(a)

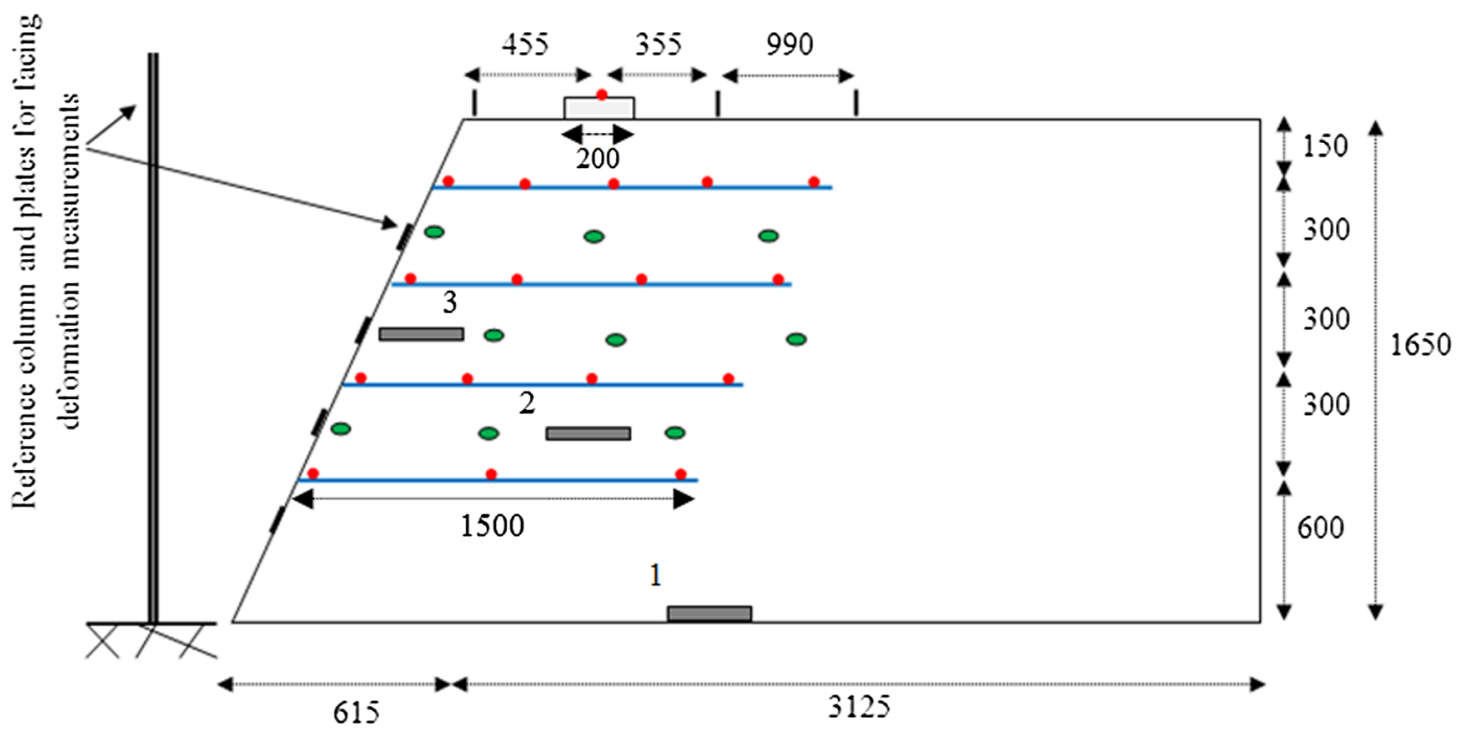

- EC5 Sensors [9] ש Earth Pressure Cells [H, V:3] - Wire Potentiometers [1S] I LVDTs [3]

(b)
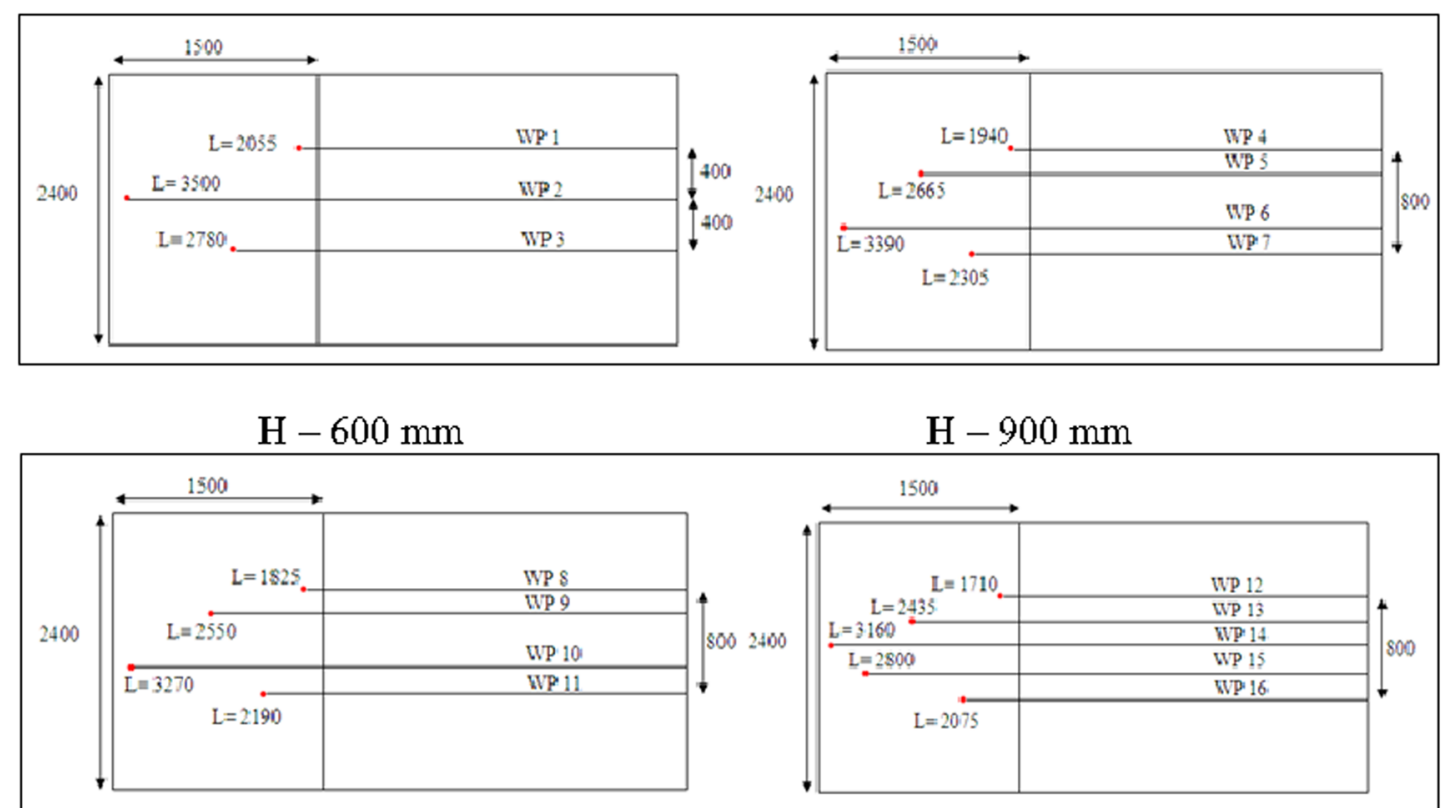

$$
\mathrm{H}-1200 \mathrm{~mm}
$$

Fig. 5 Instrumentation plan for two reinforced embankment tests: a Schematic cross-sectional view of the sensors; $\mathbf{b}$ plan views of WP extensometers at different levels; (1) all dimensions are in "mm", (2)

original sandy soil. Details of those analyses are discussed later in this paper.

On the other hand, comparison of the load-settlement results for the two embankments in Fig. 9 indicate that the wetter embankment (built at $w=12.1 \%$ ) exhibited a $48 \%$ softer initial response as compared to the all reinforcement layers were $1500 \mathrm{~mm}$ long, (3) dimensions and locations of sensors are not to scale

embankment that was built at $w=8.1 \%$. In other words, the larger failure load in the case of the model at $\mathrm{OMC}+2 \%$ was obtained at the expense of larger deformations in the embankment. Therefore, another possible explanation for larger ultimate load that was measured for the wetter embankment is that the dipping slip plane behind 

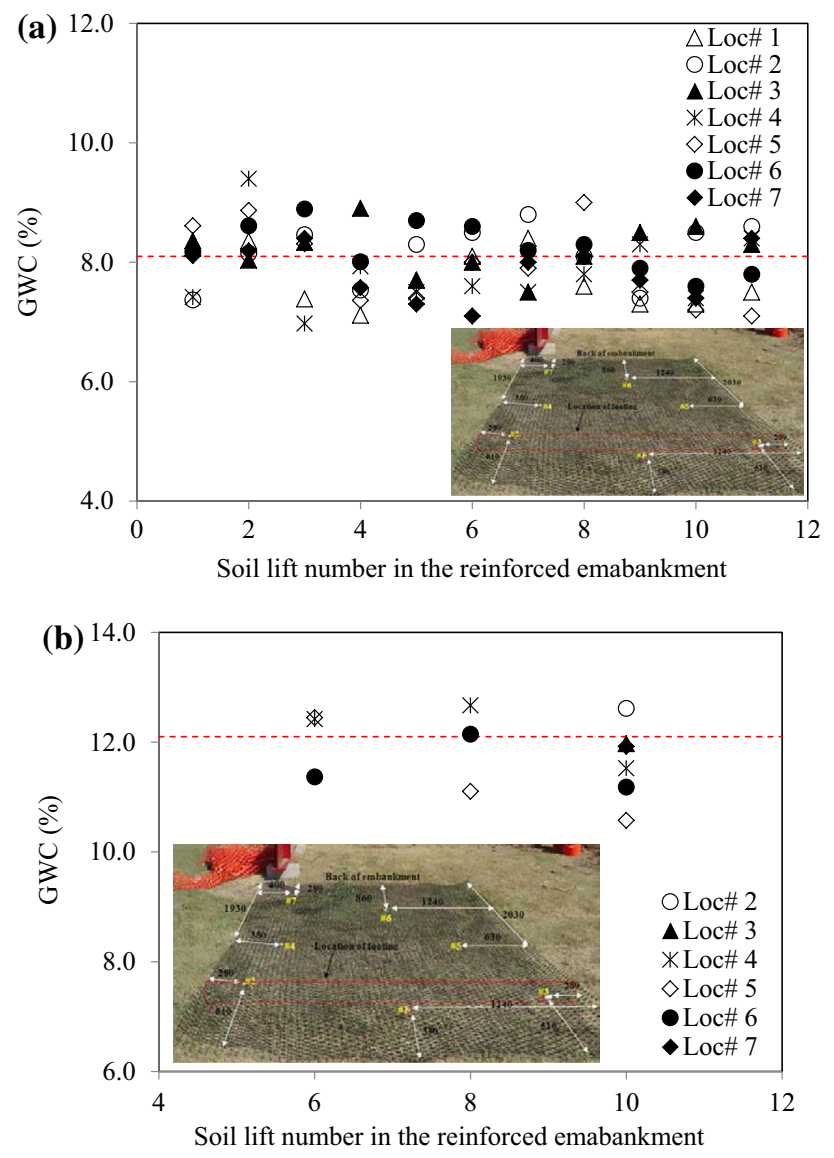

Fig. 6 Distribution of GWC within the embankment models: a Immediately before placement of the next lift (test case at OMC-2\%); b after loading and failure of the embankment for the test case at $\mathrm{OMC}+2 \%$. Horizontal dashed line indicates target $\mathrm{GWC}$ value

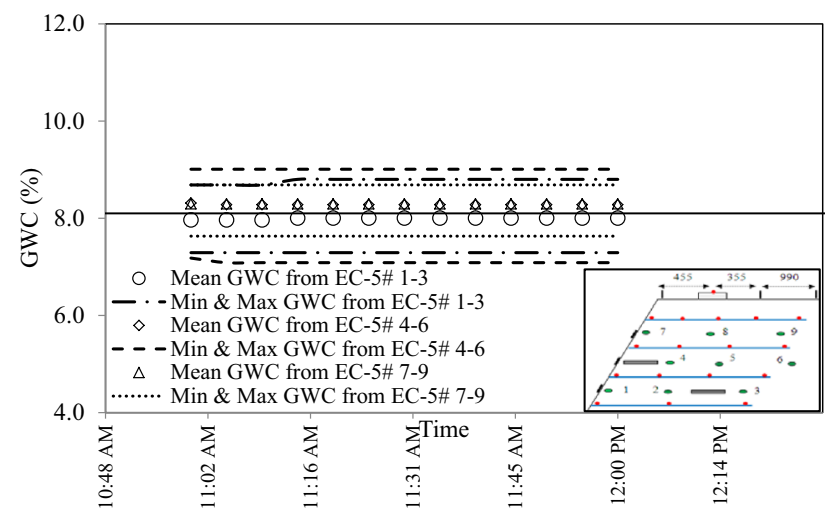

Fig. 7 Average GWC data from EC-5 sensors during the loading stage in the model embankment constructed at OMC-2 \%. Horizontal line indicates target GWC value

the loading beam in the wetter embankment might have been intercepted by the top reinforcement layers farther away from the facing than in the drier embankment. As a result, even though as evidenced by the data in Fig. 9, the

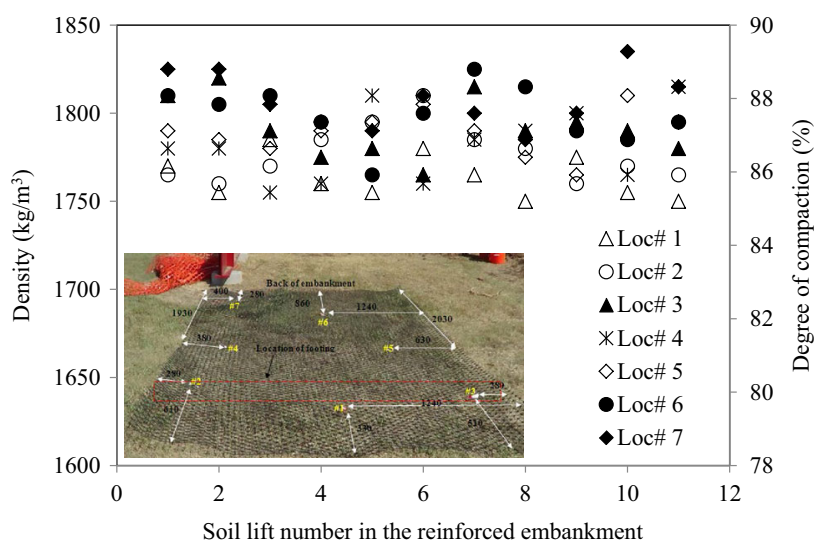

Fig. 8 Density data in the model embankment constructed at OMC-2 \% after compaction of each lift

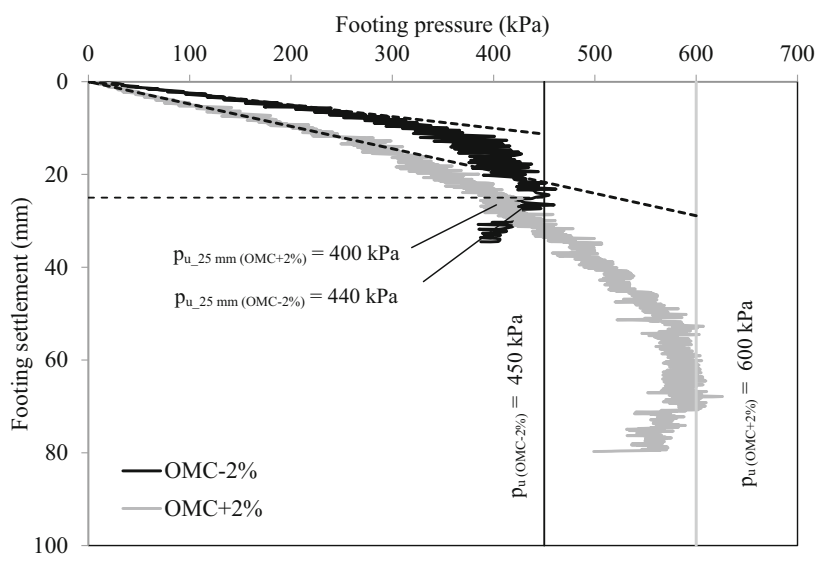

Fig. 9 Footing pressure-settlement response and failure loads of reinforced model embankments

wetter embankment consistently showed lower stiffness and load-bearing capacity throughout the entire test period for the drier embankment (due to weaker soil and soilreinforcement interfaces), a larger soil-reinforcement interface area in the wetter embankment case eventually mobilized larger reinforcement load leading to a greater ultimate failure load albeit at larger deformation. Determination of the actual reason for the greater ultimate failure load of the wetter embankment (although at larger deformation) would require further testing and analysis in a future study.

Figure 10 shows the measured (from the EPC sensors) and predicted (i.e. $\sigma=\gamma z$ ) earth pressure values within the embankment during construction and surcharge loading phases of the tests. Results in Fig. 10a indicate that measured earth pressures at all three locations in the embankment that was tested at OMC-2\% were significantly greater than the corresponding theoretical values. Additionally, the measured vertical pressures did not increase 

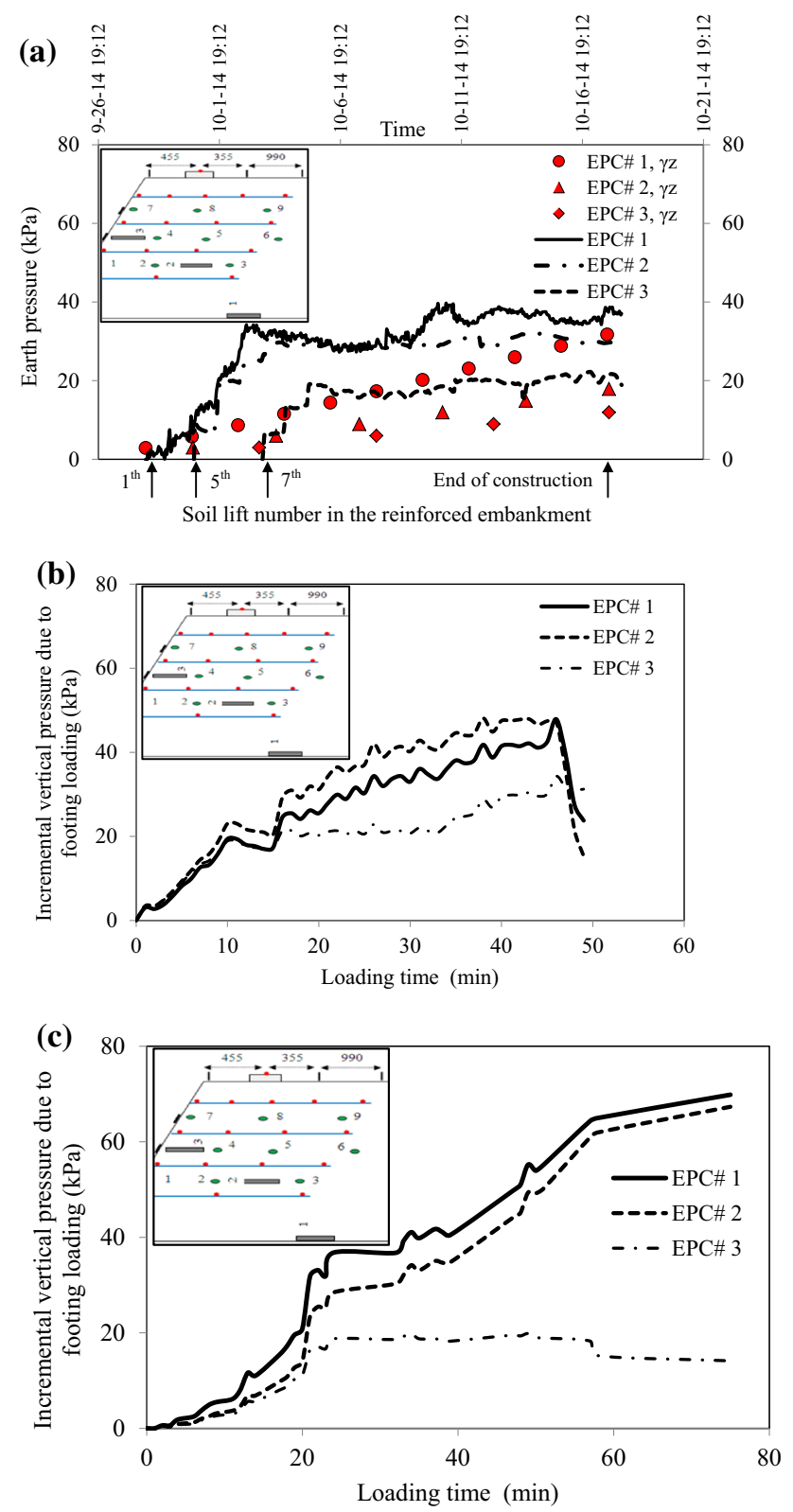

Fig. 10 Earth pressure data in the model reinforced embankments: a During construction of embankment tested at OMC-2 \%; b during surcharge loading of embankment constructed at $\mathrm{OMC}-2 \%$; and c during surcharge loading of embankment constructed at $\mathrm{OMC}+2 \%$

linearly with the number of lifts that were placed during construction. These observed differences could be primarily attributed to the influences of factors such as the weight and dynamic loading of compaction equipment and construction crew during the construction activity.

It is also observed that the differences between the measured and predicted vertical earth pressures at all locations shown in Fig. 10a are more significant earlier on during the construction period and decrease toward the end of construction. This can be attributed to the fact that the influence of construction activity on each EPC diminished as more layers of soil were placed over each sensor during construction. The magnitude of vertical earth pressure at the bottom of the embankment as measured by EPC 1 at the end of construction was $38 \mathrm{kPa}$ which is only $20 \%$ greater than the corresponding theoretical value.

Results in Fig. 10a also show that the maximum difference in vertical earth pressure at the end of construction due to construction activity was recorded by EPC 2 which is approximately $40 \%$ of the measured total earth pressure value. Results shown in Fig. 10b, c indicate that the values of maximum recorded earth pressure at failure at midheight of the slope (EPC 3) were approximately 35 and $20 \mathrm{kPa}$ for the test cases at $\mathrm{OMC}-2 \%$ and $\mathrm{OMC}+2 \%$, respectively. These values were approximately 75 and $30 \%$ of the values measured by EPC 1 and 2 in the embankment models constructed on dry and wet sides of OMC.

It is worth nothing that the embankments were initially built with a much steeper slope (nearly vertical) to facilitate construction and the facing slope was trimmed to the target slope angle as was stated previously. Therefore, the full height of the soil above EPC 3 up to the embankment surface was still practically in existence at the end of construction until the facing was trimmed before the loading phase of the tests started. As a result, the overburden pressure on EPC 3 that was calculated based on the soil weight during construction is not believed to have been influenced significantly by the slope. Also, each pressure cell was placed at the target location within the embankment at the start of the corresponding lift and was individually calibrated using a known weight and the data was recorded using its data acquisition system.

\section{Embankment Deformations}

Deformations of model embankments near the loading beam were measured using LVDTs at three different locations along the centerline of the model embankment. Figure 11 shows measured settlements of the embankment top surface during surcharge loading. Results indicate that the embankment surface behind the loading beam (LVDT 2) settled consistently throughout the loading stage but started to dilate at load levels approaching the failure load. In contrast, LVDT 1 results in Fig. 11 indicate that the embankment crest started to heave once the embankment was subjected to the strip footing load. The heaving continued throughout the test but started to reverse into settlement when the embankment approached failure. The LVDT 3 data indicate that the vertical displacement of embankment surface just outside the reinforced mass (i.e. $1345 \mathrm{~mm}$ behind the loading beam) was negligible (less than $0.1 \mathrm{~mm}$ at failure load). The LVDT results on the 

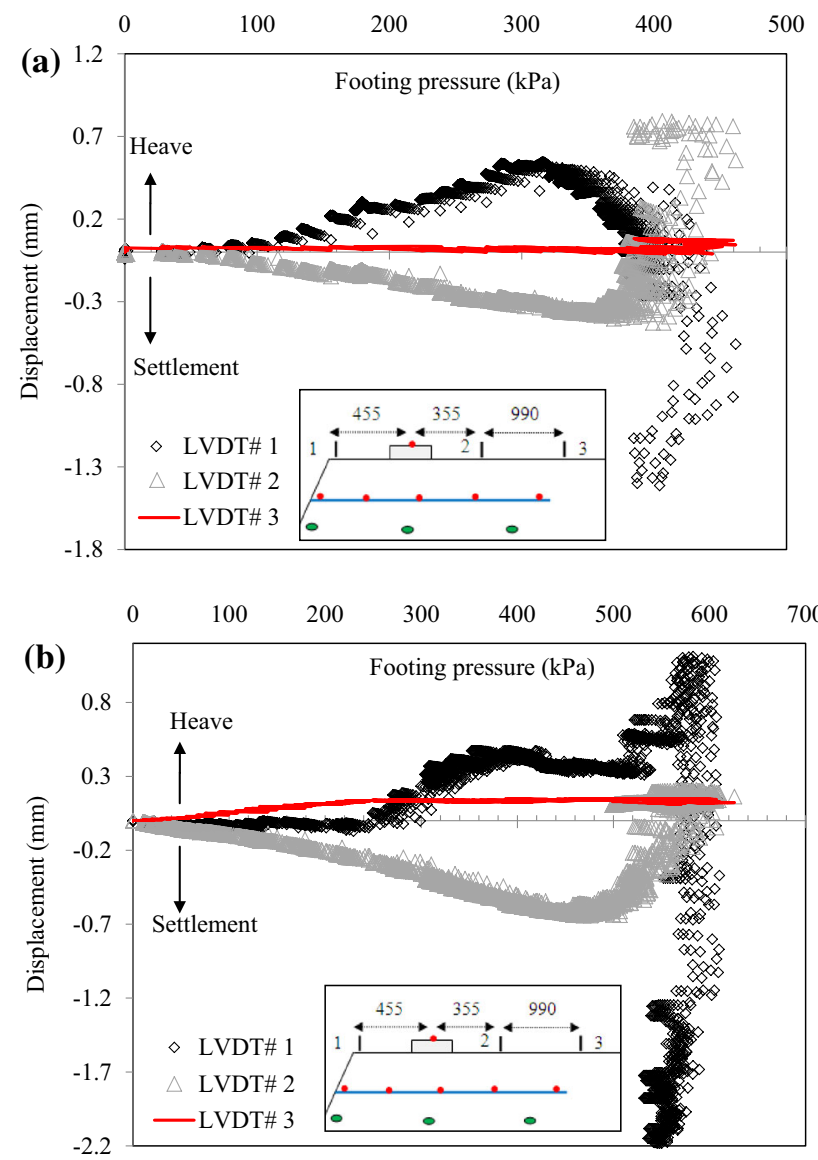

Fig. 11 Measured settlements of the embankment top surface near the footing during surcharge loading: a OMC-2\%, and b $\mathrm{OMC}+2 \%$

deformation of the embankment top surface subjected to a strip footing load as described above are consistent with the authors' recent data on reduced-scale embankment models [5-12].

Figure 12a, b show measured facing displacements of the model embankments constructed at OMC $-2 \%$ and $\mathrm{OMC}+2 \%$, respectively. Reference plate numbers that were used to measure facing displacements are indicated in the inset (also see Figs. 4b, 5a). Two additional plates were mounted at the crest level. However, they fell off the facing during surcharge loading of the embankment at OMC-2 \%. Results in Fig. 12 indicate that the deformation of the embankment facing under the strip footing load was highly concentrated near the top (i.e. in the vicinity of the 4th reinforcement layer). Essentially, a failed block slid outward over the 3rd geotextile layer by an average distance of $131 \mathrm{~mm}$ (116 and $146 \mathrm{~mm}$ on the east and west sides of the embankment, respectively) in the embankment built at $\mathrm{OMC}-2 \%$ when the test was terminated. The corresponding average slide for the model at $\mathrm{OMC}+2 \%$ was $47 \mathrm{~mm}$.
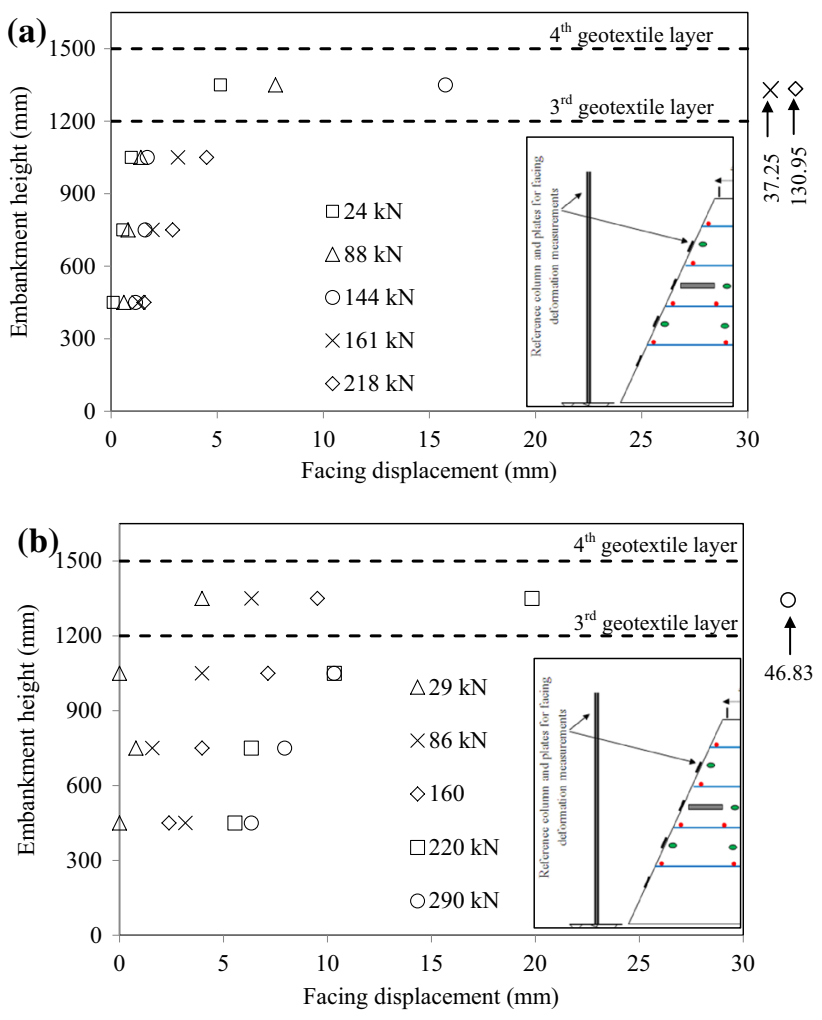

Fig. 12 Facing deformation of model embankments as measured using reference plates: a OMC $-2 \%$; and $\mathbf{b} \mathrm{OMC}+2 \%$. Each data point indicates the mean value of two measurements using two reference plates at a given elevation

\section{Geometry of Slip Surface and Geotextile Strains}

At the end of each loading test, the loading assembly was removed and excavation was started by carefully removing the soil within the failure wedge. Figure 13 shows a traced geometry of the slip plane during embankment excavation after the end of the surcharge loading phase. The failure wedge in the reinforced mass originated behind the loading beam on the surface of the embankment leading to a dipping slip plane which was intercepted by the top two (i.e. 3rd and 4th) geotextile layers as shown in Figs. 13 and 14. These figures indicate that the failure geometry was complex and involved a combination of soil shearing, pullout interaction and interface shearing along the top geotextile reinforcement in addition to interface shearing between the soil and the third geotextile layer. The traced geometry of the slip plane in Fig. 13 also indicates that the scarp of the failure plane behind the loading beam was not parallel to the slope face, which could partly be due to the influence of friction between the embankment and the sidewalls of the test box. It is worth noting that the test embankments were designed using numerical simulations with test data on component materials such that the failure plane originating from the loading beam and extending toward the 


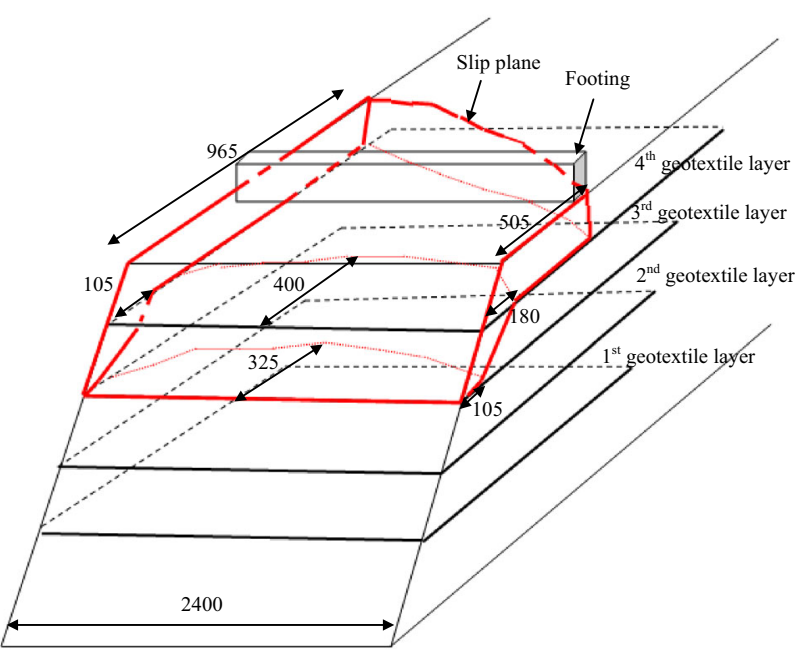

Fig. 13 Failure plane geometry as traced after careful excavation of the failed block at the end of the test constructed at OMC-2\%. All dimensions are in "mm"

embankment slope would not bypass the reinforced mass altogether and would be intercepted by one or more reinforcement layers. Results and observations in Figs. 13 and 14 confirm that this objective has been achieved. Moreover, these results clearly show that the failure mechanism in the model embankments was indeed influenced by the slope, in contrast to the case of footings on level reinforced foundations.

Figure 15a shows local displacements of the top (4th) geotextile layer and Fig. 15b shows the corresponding strain distributions at failure load (i.e. $450 \mathrm{kPa}$ ) over the length of all reinforcement layers for the test on the embankment at OMC-2 \%. Results in Fig. 15b show that the top geotextile reinforcement experienced a maximum strain of $2.4 \%$ at the front end which decreased to $0.4 \%$ toward its tail end. The strain distributions in the top reinforcement layer which experienced pullout are consistent with those from authors' earlier study on large-scale pullout tests $[5,6]$.

\section{Slope Stability Analysis}

\section{Methodology}

A series of slope stability analyses was carried out using GSTABL [19] to study the stability of reinforced embankments in the outdoor testing program. The embankments were modeled at two different GWC values of $\mathrm{OMC}-2 \%$ and $\mathrm{OMC}+2 \%$. The results for the embankment constructed at $\mathrm{OMC}-2 \%$ were validated using the first large-scale test described in this paper. The stability of an otherwise identical reinforced embankment constructed at $\mathrm{OMC}+2 \%$ was subsequently predicted using the GSTABL program.
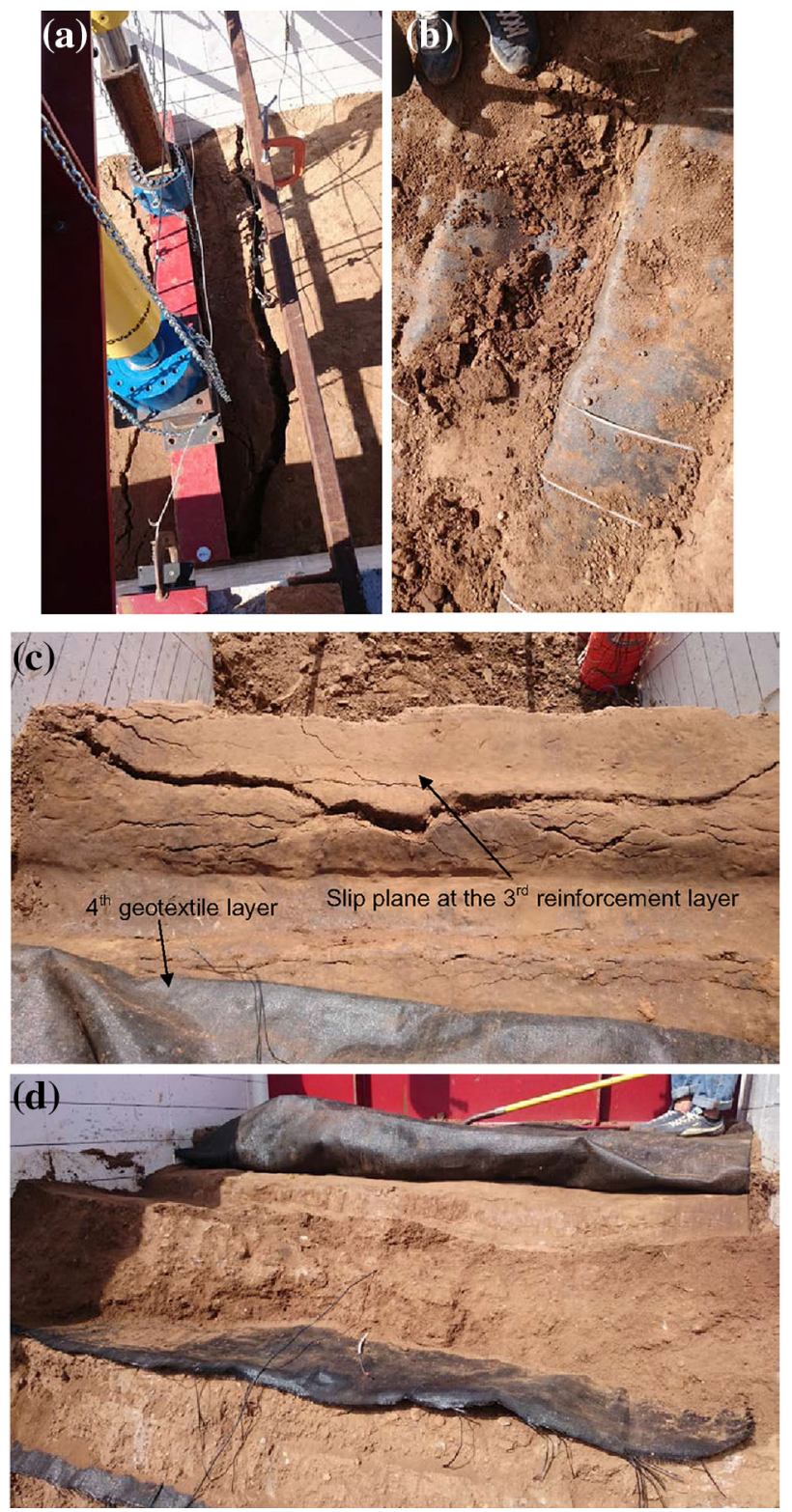

Fig. 14 Failure wedge in the embankment model tested at OMC $-2 \%$ (see the diagram in Fig. 13): a Initiation of slip plane on embankment surface; $\mathbf{b}$ (view from the top) excavated part of failure wedge above the 4th (top) geotextile layer; c (view from the top) extension of slip plane underneath the 4th geotextile layer; and d excavated part of slip plane shown in "c" which slid over the 3rd geotextile layer

Several methods were used in the stability analysis including the Janbu method of slices, the general limit equilibrium (GLE) and the Bishop method. In contrast to the GLE and Bishop methods which satisfy moment and force equilibriums (the Bishop method does not satisfy horizontal force equilibrium), the Janbu method does not satisfy moment equilibrium and only includes equilibrium of vertical and horizontal inter-slice forces. However, it 

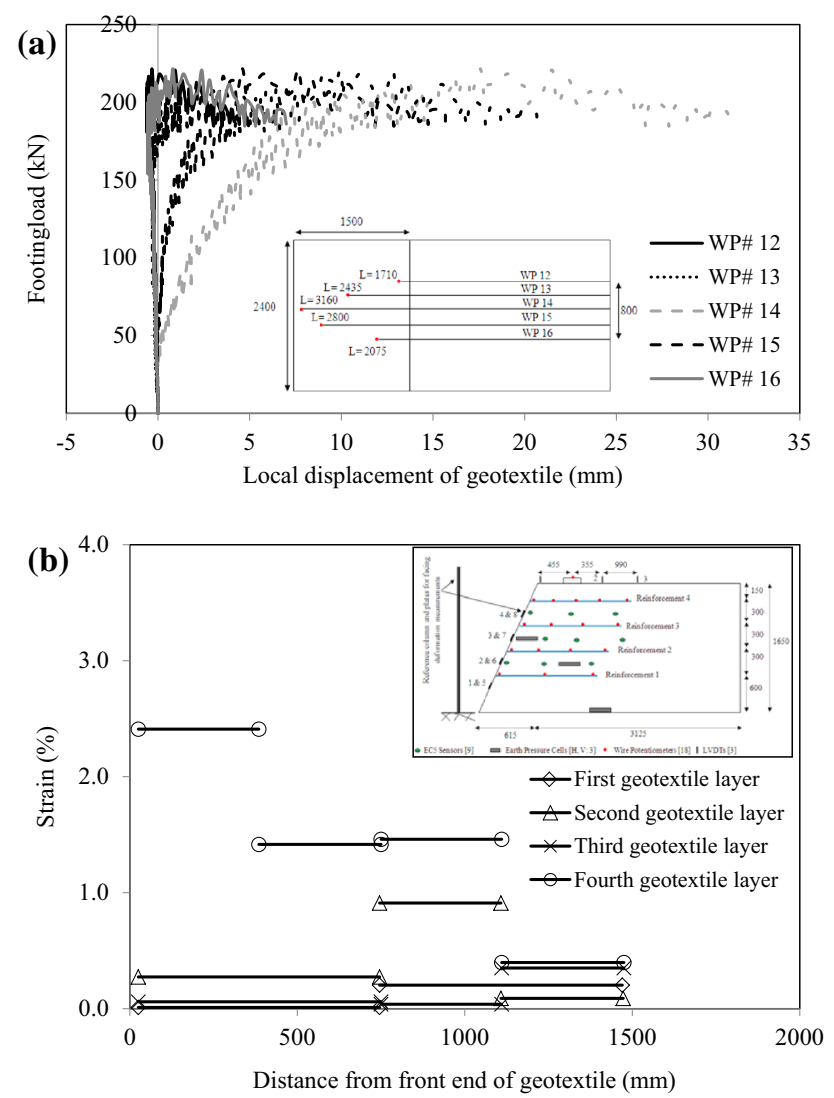

Fig. 15 a Local displacements of the top (4th) geotextile layer as measured using five wire potentiometers in the embankment at OMC $-2 \%$; and $\mathbf{b}$ strains along the length of geotextile layers for the embankment at OMC-2\%

was found that stability calculations using the Janbu method were more reasonable and comparable to the experimental data in this study.

A series of pullout tests using small-scale direct shear test apparatus (i.e. $60 \mathrm{~mm}$ square test box; $[5,6,13,26]$ ) was carried out on the embankment soil at different GWC (i.e. $\mathrm{OMC}-2 \%$ and $\mathrm{OMC}+2 \%$ ) and overburden pressure values (i.e. 50, 75 and $100 \mathrm{kPa}$ ) to determine the pullout capacity of the geotextile reinforcement per unit width $\left(P_{\mathrm{r}}\right)$ for GSTABL analysis. The gravel fraction (i.e. particles greater than Sieve \#4 [4.75 mm]) of the soil had been removed for these tests. Table 3 shows the results of pullout tests on the HP370 geotextile reinforcement in the soil that was used in the reinforced embankment tests and the corresponding MRF values. Table 4 shows the input parameters used in the GSTABL stability analysis to simulate different test cases. The average vertical stress on each reinforcement layer at the laboratory failure load was determined using the Boussinesq method [27] and the $P_{\mathrm{r}}$ values were either interpolated or extrapolated as applicable from the pullout test results. The $P_{\mathrm{r}}$ values were determined by prorating the pullout capacity values $P_{\mathrm{r}_{-} \mathrm{p}}$ by the ratio $L_{\mathrm{e}} / L_{\mathrm{p}}$ in the form:
Table 3 Pullout test data and MRF values for the reinforced embankment soil and the HP370 geotextile reinforcement at different overburden pressures

\begin{tabular}{llll}
\hline & \multicolumn{3}{l}{ Pullout strength $P_{\mathrm{r}_{\_} \mathrm{p}}(\mathrm{kN} / \mathrm{m})$} \\
\hline Overburden pressure, $\sigma_{\mathrm{v}}(\mathrm{kPa})$ & 50 & 75 & 100 \\
OMC-2 \% & 0.9 & 1.4 & 1.8 \\
OMC+2 \% & 0.7 & 1.1 & 1.4 \\
MRF & 0.77 & 0.78 & 0.78 \\
\hline
\end{tabular}

Table 4 Input parameters used in the GSTABL stability analysis

\begin{tabular}{lllllll}
\hline Soil & \multicolumn{5}{l}{ Geotextile Layer } \\
\cline { 3 - 6 } & & & 1st & 2nd & 3rd & 4th \\
\hline OMC-2\% & & & & & & \\
$\gamma\left(\mathrm{kN} / \mathrm{m}^{3}\right)$ & 19.3 & $P_{\mathrm{r}}(\mathrm{kN} / \mathrm{m})$ & 33.8 & 39.2 & 46.7 & 56.4 \\
$c(\mathrm{kPa})$ & 12.2 & & & & & \\
$\varphi\left({ }^{\circ}\right)$ & 37.5 & & & & & \\
$\mathrm{OMC}+2 \%$ & & & & & \\
$\gamma\left(\mathrm{kN} / \mathrm{m}^{3}\right)$ & 20 & $P_{\mathrm{r}}(\mathrm{kN} / \mathrm{m})^{\mathrm{a}}$ & 26.4 & 30.5 & 36.4 & 44.0 \\
$c(k P a)$ & 10.8 & & & & & \\
$\varphi\left({ }^{\circ}\right)$ & 34.3 & & & & & \\
\hline
\end{tabular}

${ }^{\mathrm{a}} P_{\mathrm{r}}$ values in the embankment at $\mathrm{OMC}+2 \%$ were calculated using the following equation: $P_{\mathrm{r}_{-} \mathrm{OMC}+2} \%=P_{\mathrm{r}_{-} \mathrm{OMC}-2} \% \times \mathrm{MRF}$

$P_{\mathrm{r}}=P_{\mathrm{r} \_\mathrm{p}} \times L_{\mathrm{e}} / L_{\mathrm{p}}$,

where $L_{\mathrm{e}}$ and $L_{\mathrm{p}}$ are the reinforcement lengths in the embankment models and in the pullout tests, respectively. The prorating of pullout capacity according to the embedment depth in Eq. 2 is based on the assumptions that: (1) the strain distribution in the extensible geotextile reinforcement used in this study is represented by a practically constant scale correction factor $\alpha$ regardless of the reinforcement length and, (2) the pullout resistance factor equals $F^{*}=\tan \delta$ in which $\delta$ is the soil-reinforcement interface friction angle. The first assumption is supported by the authors' previous studies indicating that the value of $\alpha$ for the geotextile reinforcement material used in this study in different marginal soils varied over a fairly narrow range between 0.50 and 0.64 [5, 6, 8-11]. The second assumption is consistent with the FHWA recommendations [24].

\section{Results}

\section{Model Embankment Constructed at OMC-2 \%}

Figure 16 shows the predicted factor of safety and failure geometry from the GSTABL analysis for the model embankment at OMC $-2 \%$ using the Janbu method after 
Fig. 16 GSTABL slope stability analysis results (critical slip surfaces and factors of safety $=1.086$ ) for the model embankment constructed at OMC $-2 \%$ : a Predicted FS for the reinforced embankment subjected to observed failure pressure; $\mathbf{b}$ predicted failure pressure for an equivalent unreinforced embankment with an identical FS value

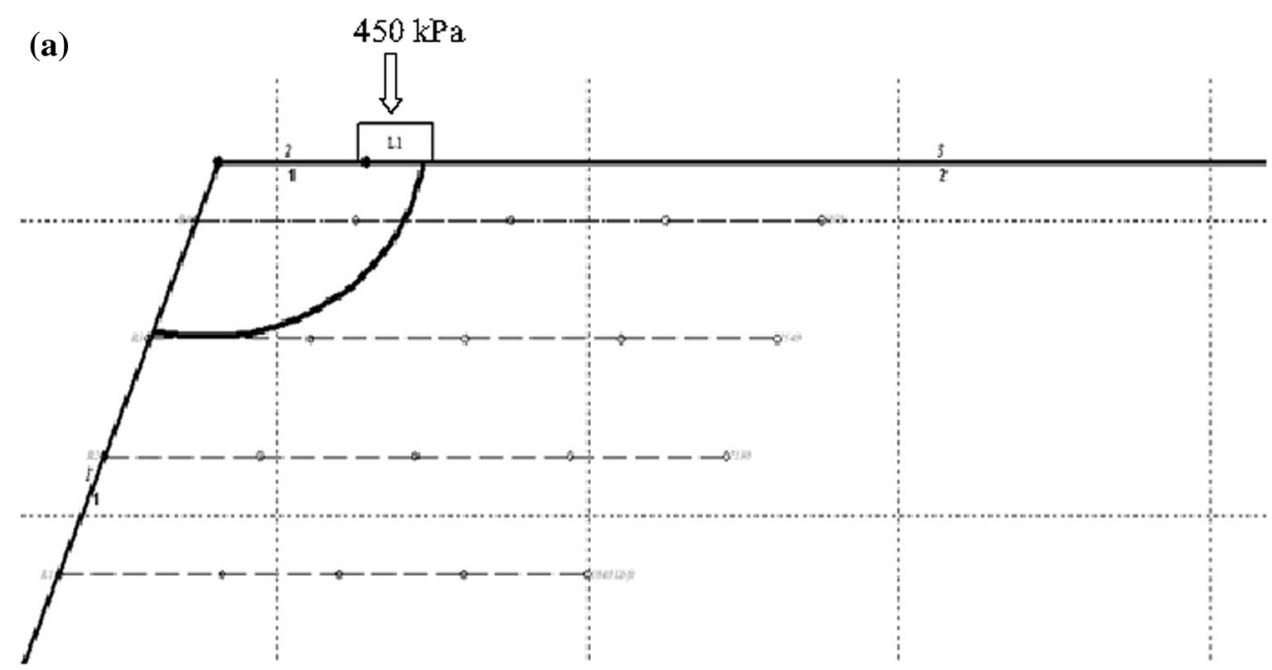

(b)

GSTABL7 *.2 FSmin-1.086

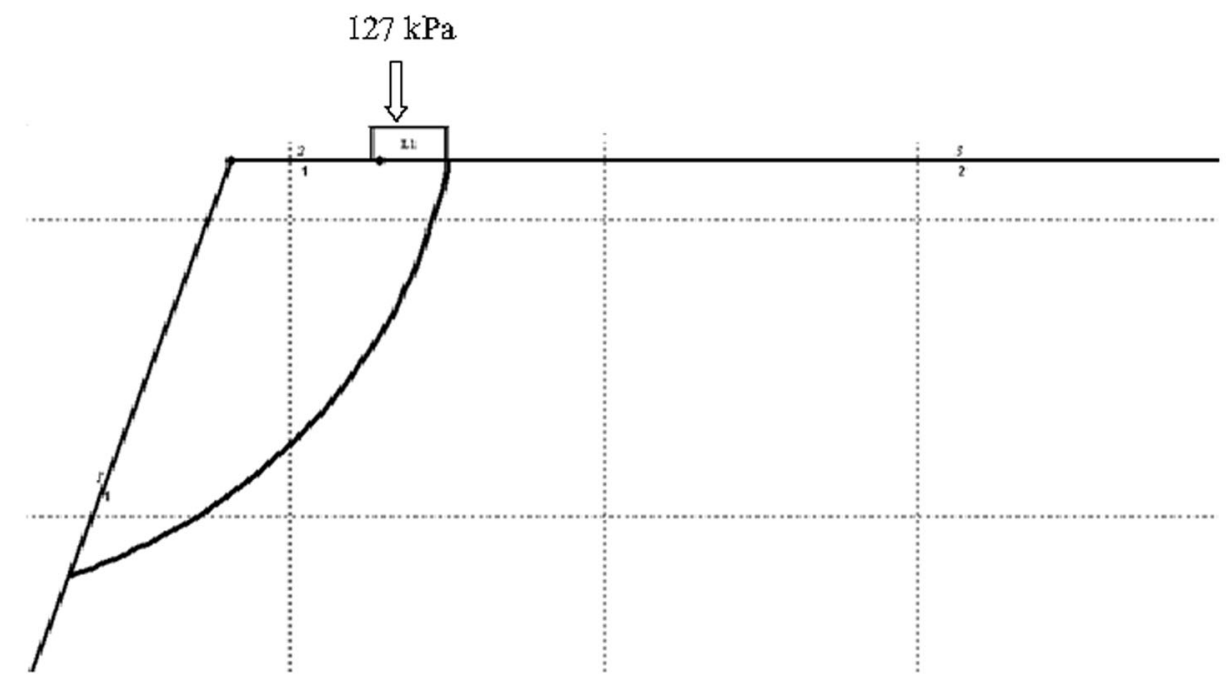

GSTABL7 Y.2 F Fmin=1.086

applying the observed experimental failure pressure (i.e. $450 \mathrm{kPa}$ ). Results in Fig. 16a indicate that the analytical slip plane intercepted the top geotextile layer and slid over the third reinforcement, which in this sense is consistent with the observations in the actual large-scale test. Also, the factor of safety obtained from GSTABL (i.e. $\mathrm{FS}=1.086)$ is reasonably close to unity, indicating impending failure. A possible improvement in both the predicted geometry of failure and the corresponding factor of safety is expected by exploring other failure geometries (e.g. a multi-part wedge analysis as opposed to a circular geometry) which is reserved for future work.
In order to quantify the contribution of reinforcement in the stability of the model embankment, the failure load of an equivalent unreinforced model corresponding to a factor of safety of 1.086 was determined to be $127 \mathrm{kPa}$ (Fig. 16b), which is $72 \%$ smaller than the value obtained for the reinforced embankment.

\section{Model Embankment Constructed at OMC+2 \%}

Figure 17 shows the predicted slip surface and factor of safety for the model embankment at $\mathrm{OMC}+2 \%$ subjected to the laboratory failure pressure of $450 \mathrm{kPa}$. Results in 
Fig. 17 Predicted slip plane and factor of safety $(\mathrm{FS}=0.937)$ for the reinforced model embankment constructed at $\mathrm{OMC}+2 \%$ and subjected to observed failure pressure from GSTABL analysis

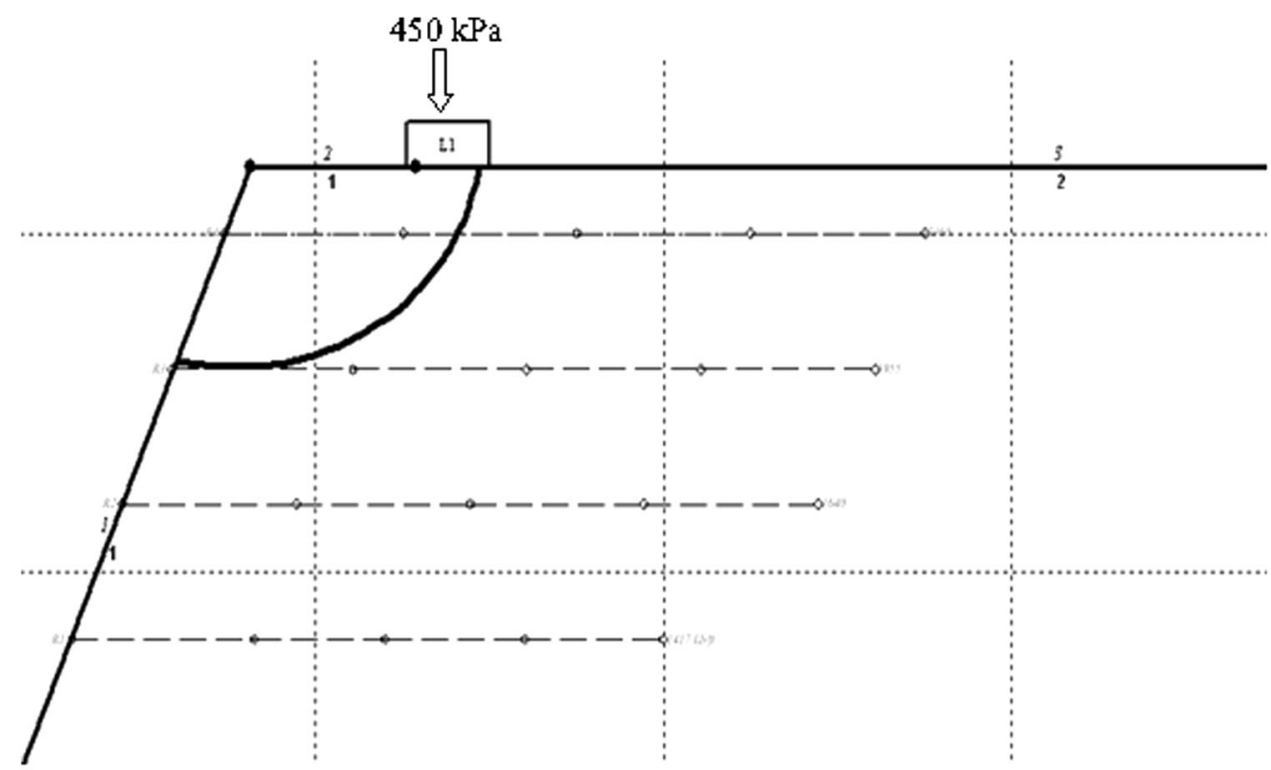

GSTABL7 v.2 FSmin=0.937

Fig. 17 indicate that the measured strength properties of the embankment soil and the corresponding MRF values for the soil-geotextile interface for the case of $\mathrm{OMC}+2 \%$ (as given in Tables 1,3 ) would have resulted in a reduction in the factor of safety of the reinforced embankment slope from 1.086 for the case of OMC-2\% to 0.937. This indicates that the embankment constructed at $\mathrm{OMC}+2 \%$ but with the exact amount of bentonite in the soil blend (2\%) should have become unstable before the failure load would reach $450 \mathrm{kPa}$ that was measured for the OMC-2\% model.

Figure 18 shows that the surcharge load needed to reach the same factor of safety obtained for the OMC-2\% model ( $\mathrm{FS}=1.086)$ for the case of embankment constructed at $\mathrm{OMC}+2 \%$ is $320 \mathrm{kPa}$. This indicates that a $22 \%$ reduction in the soil-geotextile interface strength $(\mathrm{MRF}=0.78)$ together with reduced shear strength properties of the soil as a result of wetting could result in a $14 \%$ reduction in the factor of safety of the reinforced embankment at $\mathrm{OMC}+2 \%$ as compared to the model constructed at $\mathrm{OMC}-2 \%$.

It is worth noting that in their long-term research programme leading to the present study, the authors have carried out numerous pullout and interface tests to establish the validity and accuracy of their small-scale interface tests which were used for the stability analyses reported in this paper relative to the comparable tests at much larger scale (e.g. [5, 6, 13]). Those results indicated that the small-scale cell that was used in those tests was adequate for the geotextile and the fine-grained soils that were the focus of those studies. Additionally, the slope stability results in Figs. 16 and 17 show reasonable agreements with the observed behavior in that, even with a predetermined circular geometry, both the overall size/extent of the slip plane within the reinforced embankment and the corresponding factors of safety are comparable with the experimental observations.

Therefore, the test data and analysis presented here have practical implications for practicing engineers and field projects by indicating that in the absence of a series of carefully instrumented large-scale test models that is typically the case for a given reinforced soil slope project, relatively simple and more routine analysis approaches could have the capability to predict the extent of failure geometry and factors of safety reasonably well provided that fairly accurate soil, reinforcement and interface properties are used in the analysis. In the case of fine-grained, marginal soils reinforced with geotextiles, those properties could be obtained using more commonly available and affordable test equipment at smaller scale without significant concerns about the scale effects.

\section{Summary and Conclusions}

Two large-scale $[3.7 \mathrm{~m}(L) \times 2.4 \mathrm{~m}(W) \times 1.65 \mathrm{~m}(H)]$ reinforced soil model embankments were constructed in an outdoor test facility to study the influence of their gravitational water content (GWC) on their stability and performance when subjected to a strip footing load near their 
Fig. 18 Predicted slip plane and failure load for the model embankment at $\mathrm{OMC}+2 \%$ from GSTABL analysis to reach the factor of safety equal to 1.086. White circles on the facing slope indicate the initiation points of other possible slip planes

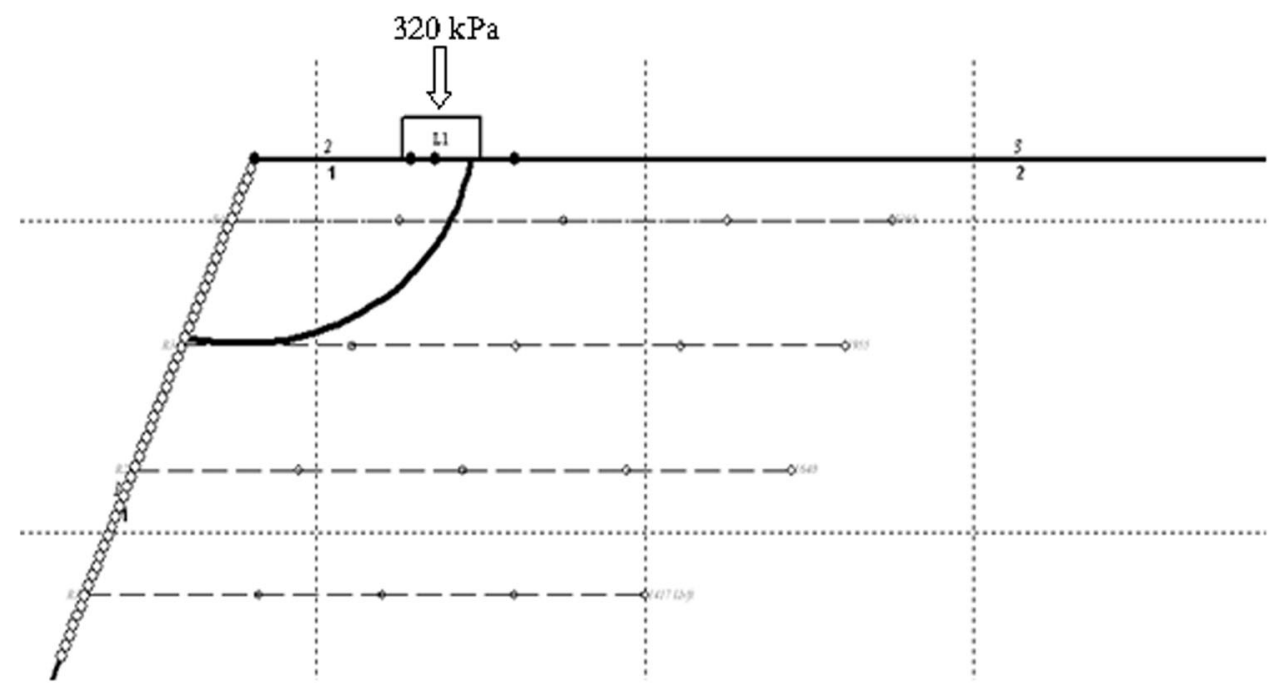

GSTABL7 v.2 FSmin=1.086 crest. These tests were part of the authors' long-term study on the influence of suction and moisture content on the shear strength of marginal soil-reinforcement interfaces that had involved multi-scale testing of interfaces and reduced-scale model embankments. The soil used in the study was a clayey sand (SC) that contained $2 \%$ by weight of sodium bentonite to represent a low-plasticity marginal quality soil in the field. One embankment was constructed at $\mathrm{OMC}-2 \%=8.1 \%$ and the other embankment was built at $\mathrm{OMC}+2 \%=12.1 \%$ to examine their comparative performance on the dry versus wet side of the optimum moisture content.

The embankments were instrumented to measure their facing deformation, settlements near the applied line load, earth pressures in the reinforced mass and moisture content throughout the embankment. Additional measurements were taken to determine the soil density and moisture content during and after construction as well as facing deformations during the loading phase of the tests.

The outdoor test facility allowed the embankments to be constructed in conditions resembling those encountered in the field while affording the researchers a comparatively controlled environment to instrument the models and study the influence of specific factors (such as moisture content and suction) on the embankments' stability and performance. The test facility was comprised of $300 \mathrm{~mm}$-thick reinforced concrete walls on three sides and a reinforced concrete floor which formed a rigid foundation for the embankments.

Comparison of load-settlement results for the two embankments indicated that the wetter embankment (built at $w=12.1 \%$ ) exhibited a $48 \%$ softer elastic response as compared to the embankment that was built at $w=8.1 \%$.
The serviceability failure load of the drier embankment based on a 25-mm settlement criterion was $212 \mathrm{kN}$ (equivalent to $440 \mathrm{kPa}$ ) which was $10 \%$ greater than the failure load obtained for the wetter embankment. However, the wetter embankment eventually failed at an ultimate pressure of $600 \mathrm{kPa}$ which was $33 \%$ greater than the ultimate load measured for the drier embankment. This unexpected result was attributed to a slightly larger concentration of sodium bentonite that might have inadvertently blended with the sandy soil during the soil processing phase of the construction operation.

The earth pressure data showed that the compactioninduced energy during construction could be significant (i.e. up to $0.7 \mathrm{\gamma h} ; h$ depth of a target point in the embankment measured from the top surface). Results of a series of limit equilibrium-based stability analyses indicated that the load bearing capacity of embankment model constructed at OMC-2\% was $40 \%$ larger when compared to an otherwise identical model at $\mathrm{OMC}+2 \%$. The same results also indicated that a $22 \%$ reduction in the soil-geotextile interface strength (i.e. $\mathrm{MRF}=0.78$ ) together with reduced shear strength properties of the soil as a result of wetting could result in a $14 \%$ reduction in the factor of safety of the reinforced embankment at $\mathrm{OMC}+2 \%$ as compared to the model that was constructed at $\mathrm{OMC}-2 \%$. Also, peak reinforcement strain in the model embankment at OMC-2\% was measured near the facing which was less than $2.5 \%$ at the corresponding failure load.

Acknowledgments The authors gratefully acknowledge the funding and support from the Oklahoma Department of Transportation (ODOT), the Oklahoma Transportation Center (OkTC) and TenCate Geosynthetics for the study reported in this paper. Contributions of 
Mr. Michael Schmitz at the Fears Structural Laboratory and undergraduate students: Keaton Zahorsky, Cody Huffine, Hannah Brashear and Michelle Basham in this project are also acknowledged.

\section{References}

1. Abu-Farsakh MY, Almohd I, and Farrag K (2006) Comparison of field and laboratory tests on geosynthetics in marginal soils. Transportation Research Record, TRR No. 1975, 124-136

2. Christopher BR, and Stulgis RP (2005) Low permeable backfill soils in geosynthetic reinforced soil walls: state-of-the-practice in North America. In: Proceedings NAGS conference, pp 14-16

3. Christopher BR, Zornberg JG, and Mitchell JK (1998) Design guidance for reinforced soil structures with marginal soil backfills. In: Proceedings of the 6th international conference on geosynthetics, Atlanta, GA, vol 1, pp 797-804

4. Dove JE, and Darden JN (2005) Native backfill materials for mechanically stabilized earth walls. Report No. VTRC 05-CR12, Virginia Department of Transportation, Richmond, VA

5. Esmaili D (2014) A study on unsaturated soil-geotextile interface strength using multi-scale laboratory tests. PhD Dissertation, The University of Oklahoma

6. Esmaili D, Hatami K, Miller GA (2014) Influence of matric suction on geotextile reinforcement marginal soil interface strength. Geotext Geomembr 42(2):139-153

7. Farrag K (1995) Evaluation of the effect of moisture content on the interface properties of geosynthetics. In: Geosynthetics'95, pp 1031-1041

8. Hatami K, Miller GA, Garcia L (2010) Use of MSE technology to stabilize highway embankments and slopes in Oklahoma. Final report OTC REOS7-1-19, Oklahoma Department of Transportation, Oklahoma City, OK

9. Hatami K, Miller GA, Esmaili D (2011) Use of MSE technology to stabilize highway embankments and slopes in Oklahoma. Final report FHWA-11-04, ODOT SPR Item 2214, Oklahoma Department of Transportation, Oklahoma City, OK

10. Hatami K, Esmaili D, Granados JE, Miller GA (2012) Pullout response of geotextile reinforcement at different matric suctions. In: 5th European geosynthetics congress, Valencia, September 2012, Paper \#136

11. Hatami K, Granados JE, Esmaili D, Miller GA (2013) Influence of gravimetric water content on geotextile reinforcement pullout resistance in MSE walls with marginal soils. Transp Res Rec 2363:66-74

12. Hatami K, Esmaili D, Chan E, Miller GA (2014) Laboratory performance of reduced-scale reinforced embankments at different moisture contents. Int J Geotech Eng 8(3):260-276

13. Hatami K, Esmaili D (2015) Unsaturated soil-woven geotextile interface strength properties from small-scale pullout and interface tests. Geosynth Int 22(2):161-172

14. Lawson C (2005) Geosynthetic reinforced MSE walls and slopes with fine grained fills: international perspectives. In: NAGS 2005/GRI-19 conference, December 2005, Las Vegas, Nevada

15. Mitchell JK, Zornberg JG (1995) Reinforced soil structures with poorly draining backfills. Part II: case histories and applications. Geosynth Int 2(1):265-307
16. Parrish BR (2006) Geotextile wrap-face wall using marginal backfill. MSc Thesis, University of Missouri-Columbia

17. Sandri D (2005) Drainage recommendations for MSE walls constructed with marginal fills. In: NAGS 2005/GRI-19 conference, December 2005, Las Vegas, Nevada

18. Zornberg JG, Mitchell JK (1994) Reinforced soil structures with poorly draining backfills. Part I: reinforcement interactions and functions. Geosynth Int 1(2):103-148

19. Gregory Geotechnical Software (2003) GSTABLE, Version 2.0

20. ASTM International (2007) Standard test method for particle size analysis of soils. American Society for Testing and Materials, West Conshohocken

21. ASTM International (2006) Standard test method for amount of material in soils finer than No. $200(75-\mu \mathrm{m})$ sieve. American Society for Testing and Materials, West Conshohocken

22. ASTM International (2010) Standard test method for laboratory determination of water (moisture) content of soil and rock by mass. American Society for Testing and Materials, West Conshohocken

23. ASTM International (2008) Standard test method for density and unit weight of soil in place by the rubber balloon method. American Society for Testing and Materials, West Conshohocken

24. Berg RB, Christopher BR, Naresh CS (2009) Design and construction of mechanically stabilized earth walls and reinforced slopes. Federal Highway Administration, FHWA-NHI-10-024, Washington, DC

25. De Blasio FV (2011) Friction, cohesion and slope stability. Introduction to the physics of landslides: lecture notes on the dynamics of mass wasting. pp 23-52, doi: 10.1007/978-94-0071122-8_2

26. Bareither CA, Benson CH, Edil TB (2008) Comparison of shear strength of sand backfills measured in small-scale and large-scale direct shear tests. Can Geotech J 45:1224-1236

27. Budhu M (2000) Soil mechanics and foundations, 1st edn. Wiley, Hoboken

28. ASTM International (2012) Standard test method for laboratory compaction characteristics of soil using modified effort. American Society for Testing and Materials, West Conshohocken

29. ASTM International (2011) Standard test method for direct shear tests of soils under consolidated drained conditions. American Society for Testing and Materials, West Conshohocken

30. ASTM International (2009) Standard test method for tensile properties of geotextiles by the wide-width strip method. American Society for Testing and Materials, West Conshohocken

31. ASTM International (2014) Standard test method for strength of sewn or bonded seams of geotextiles. American Society for Testing and Materials, West Conshohocken

32. ASTM International (2014) Standard test method for water permeability of geotextiles by permittivity. American Society for Testing and Materials, West Conshohocken

33. ASTM International (2012) Standard test method for determining apparent opening size of geotextile. American Society for Testing and Materials, West Conshohocken

34. ASTM International (2013) Standard test method for determining the shear strength of soil-geosynthetic and geosynthetic-geosynthetic interfaces by direct shear. American Society for Testing and Materials, West Conshohocken 